\title{
Moment capacity estimation of spirally reinforced concrete columns using ANFIS
}

\author{
Hosein Naderpour ${ }^{1} \cdot$ Masoomeh Mirrashid $^{1}$ (D)
}

Received: 3 June 2018 / Accepted: 12 August 2019 / Published online: 23 August 2019

(C) The Author(s) 2019

\begin{abstract}
This paper presents a predictive model based on adaptive neuro-fuzzy inference system namely ANFIS to determine the moment capacity of spiral-reinforced concrete columns. For this purpose, five input parameters including the longitudinal reinforcement index, transverse reinforcement index, axial force, diameter to length ratio and also shear force were considered to estimate the moment capacity. A collection of experimental database was applied to train and test the proposed system. This database includes 82 spiral-reinforced concrete columns (with flexure failure) which were reported in the literature and modified by PEER as a uniform database of cantilever columns. The model is created by fuzzy C-means algorithm with four cluster and Gaussian membership functions, also trained and tested by 70 and 12 datasets, respectively. It was concluded that the model of this study with high accuracy could be able to estimate the moment capacity.
\end{abstract}

Keywords Flexure failure $\cdot$ Moment capacity $\cdot$ Neuro-fuzzy system $\cdot$ Reinforced concrete $\cdot$ Spiral-reinforced concrete column

\section{Introduction}

One of the most complex issues in structural engineering is the investigation of the structural elements behaviors and estimation of final capacities. This issue is essential in determining the damages and the failures of elements under loading such as an earthquake. There are many efforts to investigate this topic which were published in the literature, and some of them are reviewed here by the authors. Panagiotako et al. [1] studied the effect of capacity design for Reinforced Concrete (RC) column under seismic loading and showed that in some cases, damage of the element could not be prevented by full capacity design. Hernandez et al. [2] investigated the effect of longitudinal reinforcement on the capacity of concrete columns and presented a method to determine a suitable combination of reinforcement. An experimental study on the compressive capacity of RC columns was done by Chen et al. [3]. They presented an analytical approach for

Masoomeh Mirrashid

m.mirrashid@semnan.ac.ir

Hosein Naderpour

naderpour@semnan.ac.ir

1 Faculty of Civil Engineering, Semnan University, Semnan 3513119111, Iran their purpose and based on the experimental results, showed that their method could determine the considered behavior of special-shaped reinforced concrete columns. Some researchers studied the capacity of RC columns which made by recycled aggregate [4-6].

Today, soft computing (SC) has many applications in engineering problems [7-10]. There are numerous articles on the use of SC in civil engineering such as earthquakes [11, 12] dams [13], concrete [14] and structural control [15]. Also, these methods are considered to estimate the capacity of structural elements [16, 17] instead of finite element analysis which is a time-consuming approach $[18,19]$. Liu et al. [20] studied the application of artificial neural networks to predict the shear strength of RC columns and verified their model with an experimental database. Jakubek [21] used fuzzy weight neural networks to predict the critical axial load of bulking tests in RC columns. Xu et al. [22] identified the seismic damages of RC columns by neural networks based on images. Their results indicated that these soft computing approaches could be used for damage detection of RC columns.

The current research investigated the application of a powerful soft computing approach namely ANFIS (adaptive neuro-fuzzy inference system) to determine the moment capacity in spiral-reinforced concrete columns. The 
presented model is trained and tested by a collection of the experimental database. Details of the proposed ANFIS structure are provided in the mathematical framework to increase the ability to use it by engineers.

\section{ANFIS}

Adaptive neuro-fuzzy inference system (ANFIS) is a fuzzy inference model in a neural network structure for function approximation [23]. It used a Sugeno-type fuzzy system in the five-layer network [23]. ANFIS contains an input vector with some Membership Function (MF) for each input. ANFIS used a hybrid approach, which is a combination of backpropagation and least squares methods, to find its unknown parameters. This type of soft computing method is widely considered as a powerful system because it has the ability of both artificial neural networks and fuzzy systems simultaneously [7, 23-31].

\section{Database}

Neuro-fuzzy inference system needs a database to determine its unknown coefficients, and in this paper, a collection of spiral-reinforced columns tests results, which were presented by other researchers [32-65] and modified by PEER [66], was used. This database contains three types of cantilever column including octagonal, circular and square. More information can be seen in the PEER report. Also, five input variables

Table 1 Description of the considered variables

\begin{tabular}{lll}
\hline Parameter & Notation & Description \\
\hline Input 1 & $X_{1}$ & Longitudinal reinforcement index \\
Input 2 & $X_{2}$ & Transverse reinforcement index \\
Input 3 & $X_{3}$ & Axial force $(\mathrm{kN})$ \\
Input 4 & $X_{4}$ & $D / L^{\mathrm{a}}$ \\
Input 5 & $X_{5}$ & Shear load $(\mathrm{kN})$ \\
Output & $M$ & Moment capacity $(\mathrm{kN} \mathrm{m})$ \\
\hline
\end{tabular}

${ }^{\text {a }} D$ diameter of column (mm), $L$ length of equivalent cantilever $(\mathrm{mm})$ which are described in Table 1 and presented in "Appendix" are used in this study. The two first parameters can also be defined by Eqs. 1 and 2:

$x_{1}=\frac{\rho_{1} f_{\mathrm{yl}}}{f_{\mathrm{c}}^{\prime}}$,

$x_{2}=\frac{\rho_{\mathrm{s}} f_{\mathrm{ys}}}{f_{\mathrm{c}}^{\prime}}$,

where $\rho_{1}, f_{\mathrm{yl}}, \rho_{\mathrm{s}}, f_{\mathrm{ys}}, f_{\mathrm{c}}^{\prime}$ are longitudinal reinforcement ratio $(\%)$, the yield stress of longitudinal reinforcement (MPa), volumetric transverse reinforcement ratio (\%), the yield stress of transverse reinforcement (MPa) and also the compressive strength of concrete ( $\mathrm{MPa})$, respectively. Table 2 shows the details of the collected database.

In this paper, the authors used Eq. 3 as a normalization relationship to convert all amounts of the database into a value between -1 and +1 . In this equation, the parameters $x_{n}, x_{\min }, x_{\max }$ are indicated to the normal, minimum and maximum values of $x_{i}$.

$x_{n}=2 \frac{x_{i}-x_{\min }}{x_{\max }-x_{\min }}-1$

Based on Table 2 and also Eq. 3, the amount of the variables is normalized by Eqs. 4-9 before using in training and testing the proposed ANFIS model.

$X_{1}=2 \frac{x_{1}-6.78}{65.60}-1$

$X_{2}=2 \frac{x_{2}-1.05}{36.99}-1$

$X_{3}=2 \frac{x_{3}}{6770}-1$

$X_{4}=2 \frac{x_{4}-0.07}{0.6}-1$
Table 2 Description of the considered parameters

\begin{tabular}{lrrrrrr}
\hline Parameter & \multicolumn{1}{c}{$X_{1}$} & \multicolumn{1}{c}{$X_{2}$} & \multicolumn{1}{c}{$X_{3}$} & \multicolumn{1}{c}{$X_{4}$} & \multicolumn{1}{c}{$X_{5}$} & \multicolumn{1}{c}{$M$} \\
\hline Minimum & 6.78 & 1.05 & 0.00 & 0.07 & 14.00 & 22.00 \\
Maximum & 72.37 & 38.05 & 6770.00 & 0.67 & 957.00 & 1300.00 \\
Median & 27.86 & 12.72 & 552.50 & 0.22 & 136.00 & 220.00 \\
Average & 30.15 & 14.48 & 917.33 & 0.27 & 199.87 & 368.28 \\
St. deviation & 13.70 & 7.16 & 1078.75 & 0.14 & 209.56 & 340.19 \\
Mode & 15.27 & 13.70 & 222.00 & 0.22 & 77.00 & 394.00 \\
Range & 65.60 & 36.99 & 6770.00 & 0.60 & 943.00 & 1278.00 \\
\hline
\end{tabular}


$X_{5}=2 \frac{x_{5}-14}{943}-1$

$Y=2 \frac{M-22}{1278}-1$

\section{Proposed ANFIS model}

As mentioned in the previous sections, ANFIS uses some membership functions for each input. In this research, four Gaussian membership functions (Eq. 10) were used for each of the five inputs in the proposed ANFIS structure (Fig. 1). The parameters of the membership functions for all inputs are presented in Table 3. These functions can be seen in Fig. 2:

$C_{i}(x ; \sigma, c)=\mathrm{e}^{\frac{-(x-c)^{2}}{2 \sigma^{2}}}$, where $c$ is the mean and $\sigma$ is the variance for $x$.

The proposed ANFIS uses linear-type functions (Eq. 5) as the output of each node with five coefficients and one constant value. Table 4 presents the details of these linear functions and their coefficients.

$f_{j}=a_{1 j} X_{1}+a_{2 j} X_{2}+a_{3 j} X_{3}+a_{4 j} X_{4}+a_{5 j} X_{5}+C_{j} \quad j=1, \ldots, 4$,

where $X_{i}$ is the normalized value of inputs and $a_{1}, \ldots, a_{5}$ are coefficients of the linear function. $C$ is also the constant value of the equation. In this equation, $j$ denotes the number of linear functions.

There are four rules in the proposed ANFIS. The weight of each rule $W_{i}(j=1, \ldots, 4)$ is calculated by Eq. 12 . In these equations, MF is a membership function value of each input, which can be calculated by Eq. 10 based on the presented amounts of Table 3.
Fig. 1 Proposed ANFIS structure

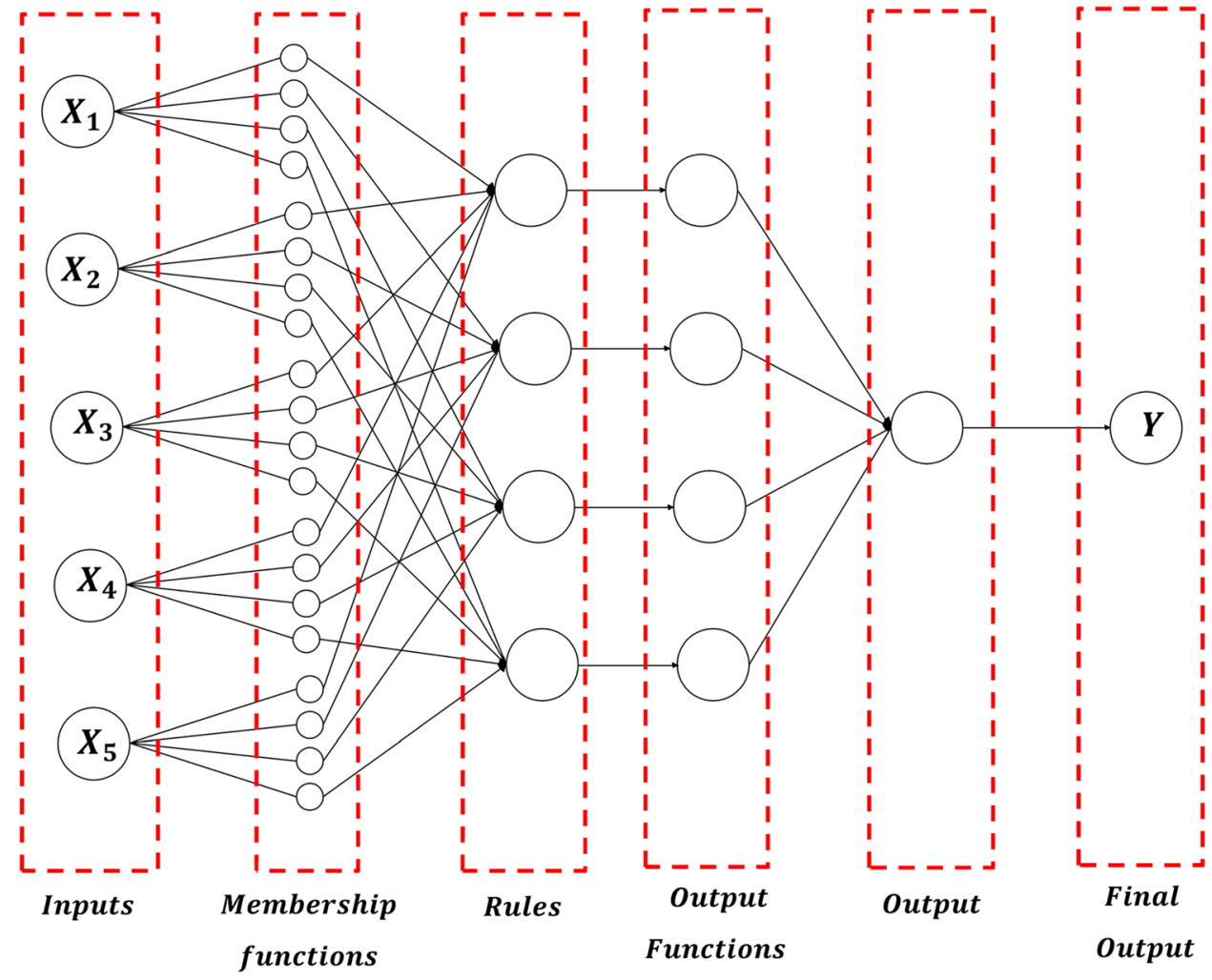

Table 3 Details of the membership function

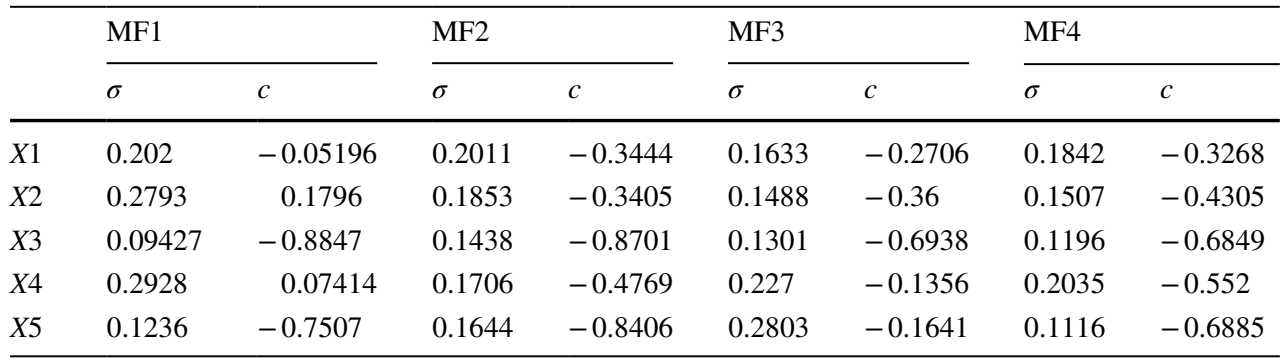



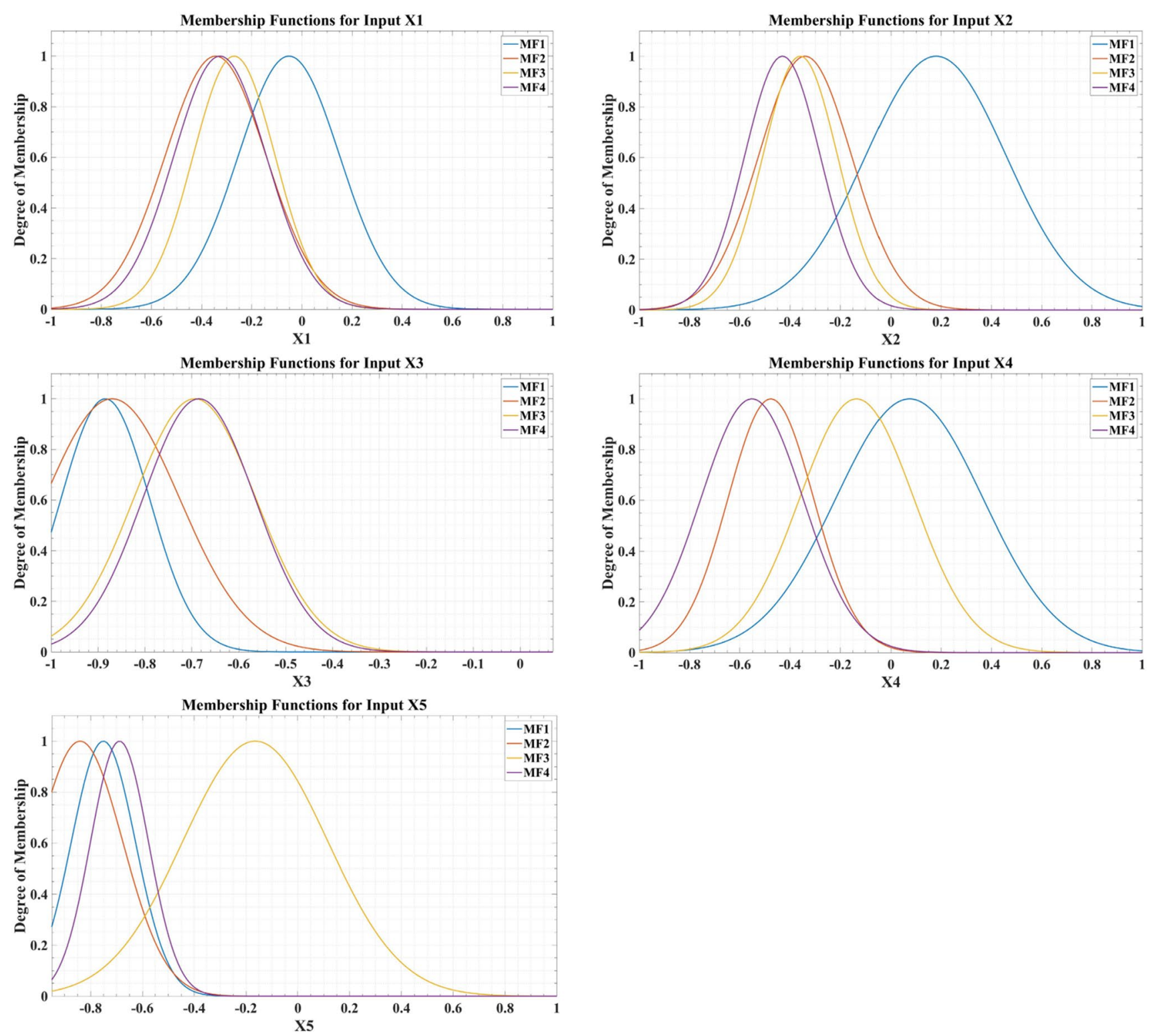

Fig. 2 Membership functions of the input parameters

Table 4 The parameters of Eq. 11

\begin{tabular}{lrrrrrr}
\hline Function & \multicolumn{2}{l}{ Coefficients } & \multicolumn{1}{c}{} & \multicolumn{2}{c}{ Constant } \\
\cline { 2 - 6 } & \multicolumn{1}{l}{$a_{1}$} & \multicolumn{1}{c}{$a_{2}$} & \multicolumn{1}{c}{$a_{3}$} & \multicolumn{1}{c}{$a_{4}$} & \multicolumn{1}{c}{$a_{5}$} & \multicolumn{1}{c}{$C$} \\
\hline$f_{1}$ & -0.0351 & -0.0275 & 0.0110 & -0.0642 & 0.4107 & -0.5734 \\
$f_{2}$ & 0.1251 & 0.2258 & -0.0757 & -0.2742 & 0.8458 & -0.2343 \\
$f_{3}$ & -0.3503 & -0.0999 & -0.1728 & -1.5300 & 1.6980 & -0.0266 \\
$f_{4}$ & -0.1095 & 0.0262 & -1.4740 & -1.9110 & 4.2500 & 1.0400 \\
\hline
\end{tabular}

$W_{1}=\mathrm{MF}_{1, X 1} \mathrm{MF}_{1, X 2} \mathrm{MF}_{1, X 3} \mathrm{MF}_{1, X 4} \mathrm{MF}_{1, X 5}$

$W_{2}=\mathrm{MF}_{2, X 1} \mathrm{MF}_{2, X 2} \mathrm{MF}_{2, X 3} \mathrm{MF}_{2, X 4} \mathrm{MF}_{2, X 5}$

$W_{3}=\mathrm{MF}_{3, X 1} \mathrm{MF}_{3, X 2} \mathrm{MF}_{3, X 3} \mathrm{MF}_{3, X 4} \mathrm{MF}_{3, X 5}$

$W_{4}=\mathrm{MF}_{4, X 1} \mathrm{MF}_{4, X 2} \mathrm{MF}_{4, X 3} \mathrm{MF}_{4, X 4} \mathrm{MF}_{4, X 5}$
The final output of the proposed ANFIS model is determined by Eq. 13:

$-1 \leq\left(Y=\frac{\sum_{j=1}^{4} W_{j} f_{j}}{\sum_{j=1}^{4} W_{j}}\right) \leq 1$. 
Fig. 3 Regression plots of the results based on normal values

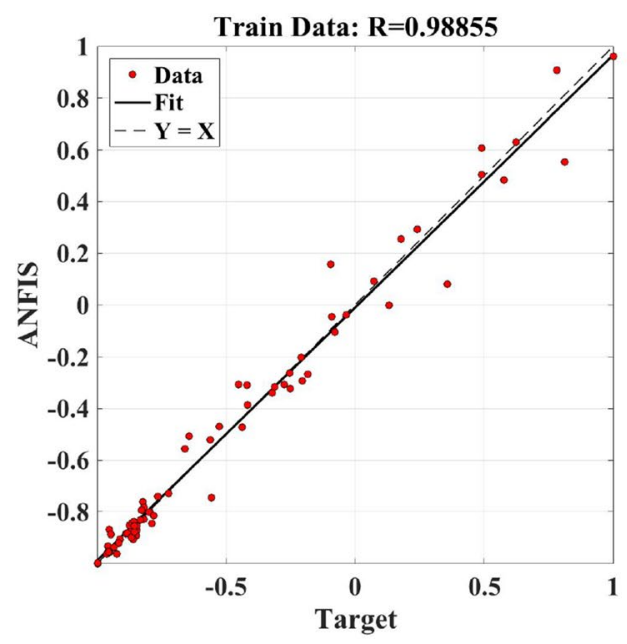

As mentioned in the previous section, the result of the ANFIS is a normal value between -1 and 1 , and therefore, it needs to convert to the corresponding real value (22-1300 $\mathrm{kN} \mathrm{m}$ ) by Eq. 14:

$M(\mathrm{kN} \mathrm{m})=1278 \frac{Y+1}{2}+22$.

\section{Results of the ANFIS}

The training of the proposed system was done by 70 datasets, and the results of this phase showed that the model was trained very well. Also, to validate the ANFIS, 12 datasets were applied to the trained system. The results of regression plots (Fig. 3) for the normal values showed the correlation coefficients equal to 0.99 and 0.98 for the train and test phases, respectively.

Figure 4 shows the obtained results by ANFIS against the experimental values after converting the normalized values into their corresponding real values for the considered database. It is clear from the figure that the proposed ANFIS was able to estimate the moment capacity of spiral-reinforced concrete columns.

The amount of root means squared error for the train, and test phases (Figs. 5, 6) were 50.36 and 92.11 which was shown that the ANFIS could be used as a suitable tool for
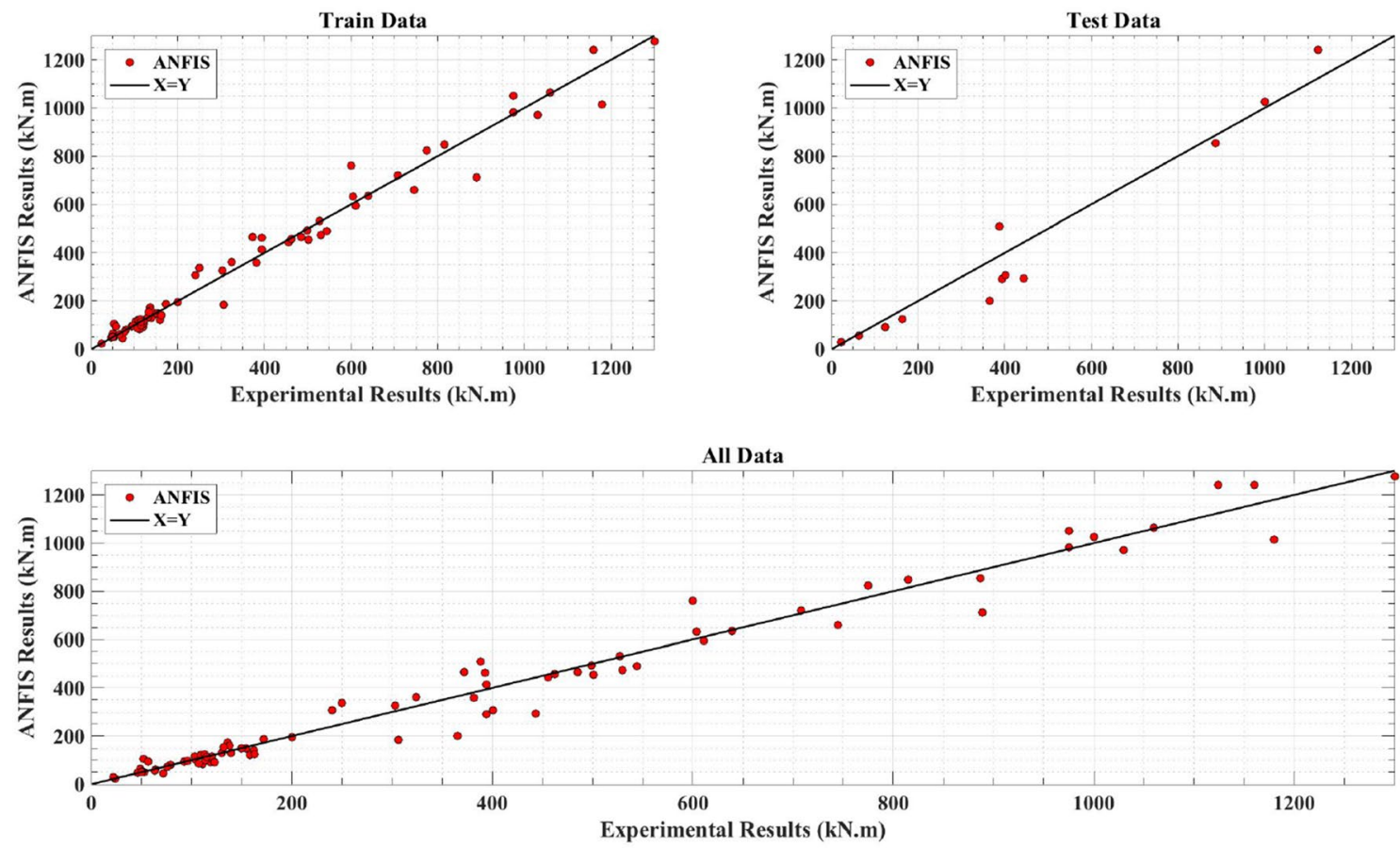

Fig. 4 The results of the ANFIS vs. experimental values 

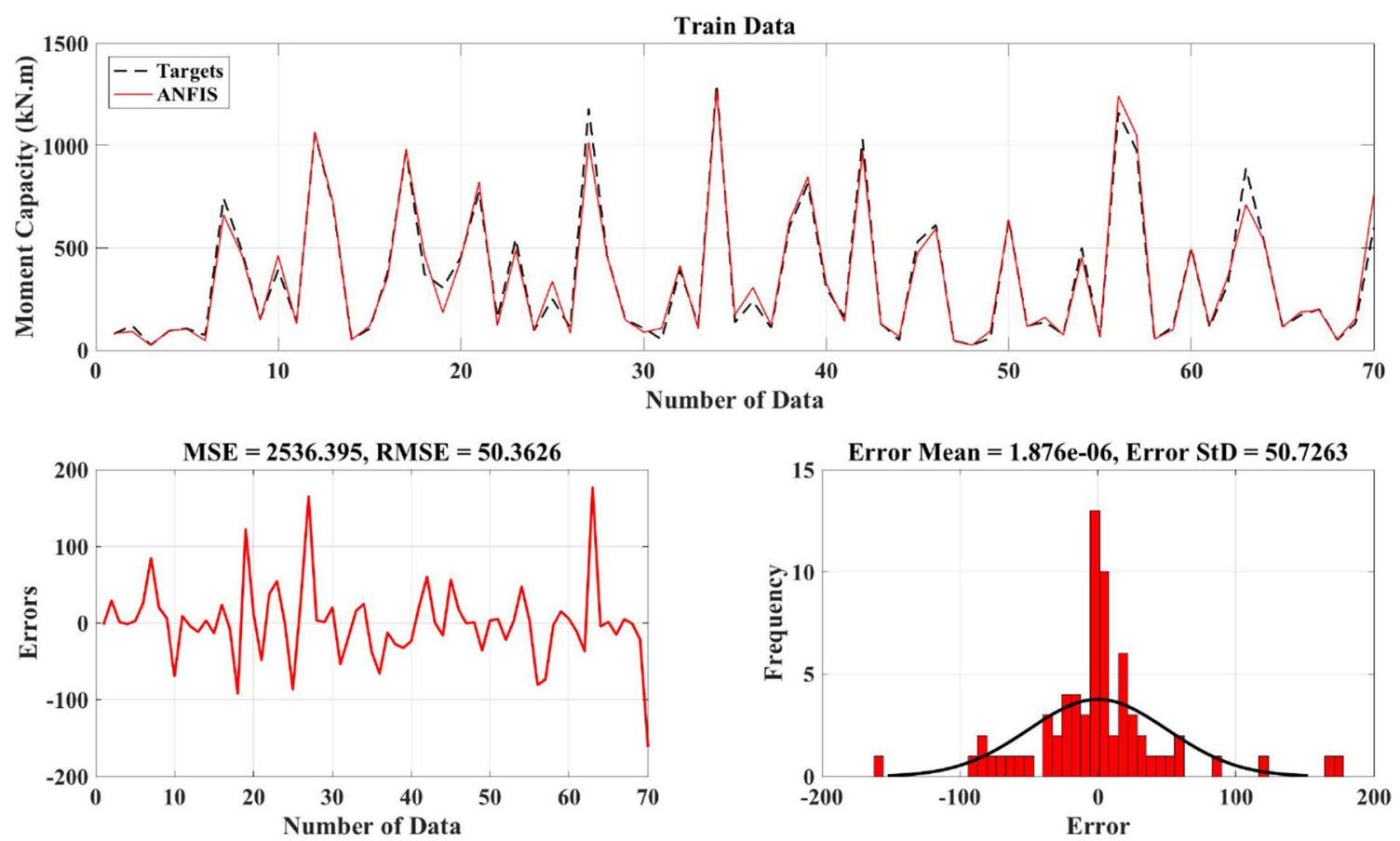

Fig. 5 Results for the train data
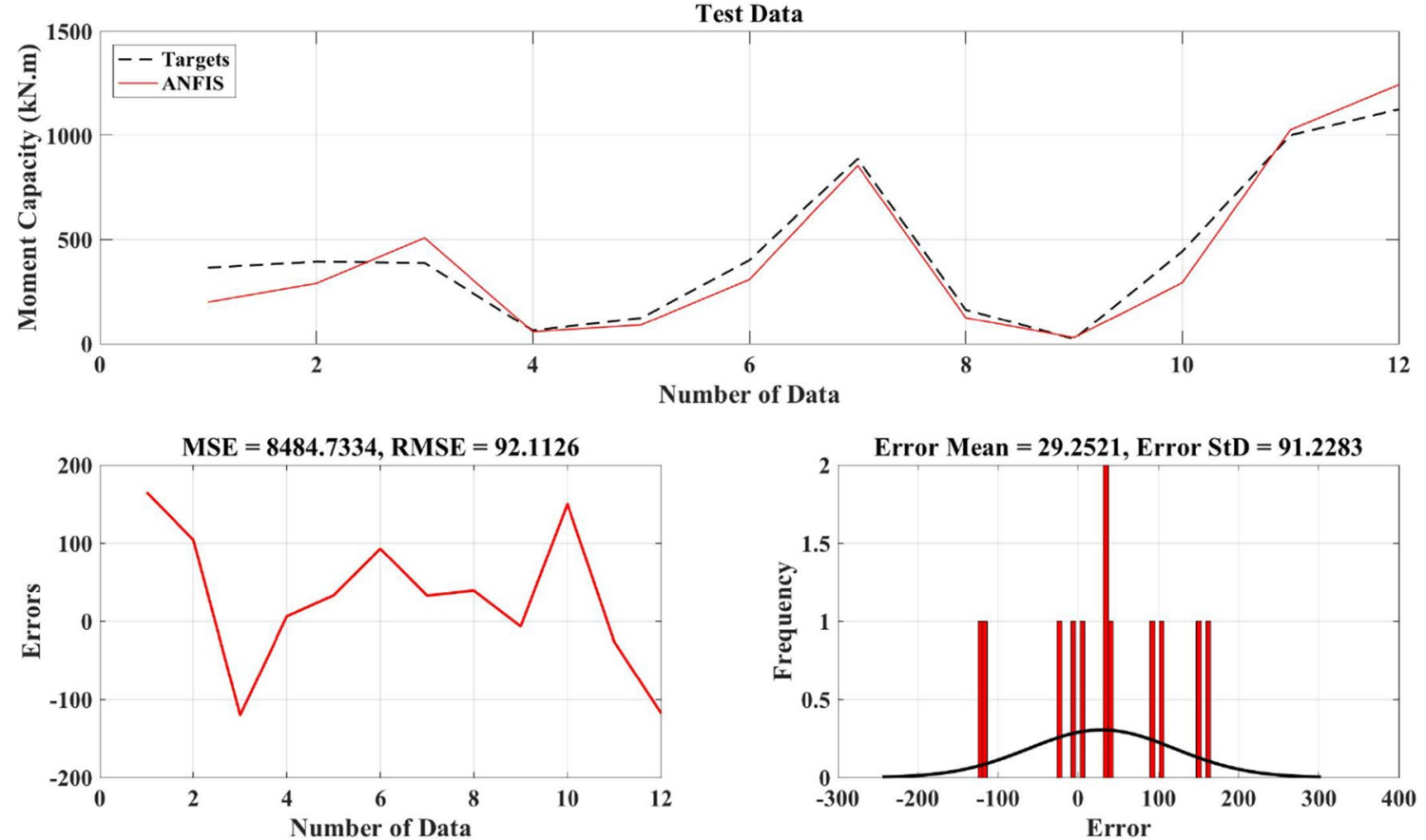

Fig. 6 Results for the test data 

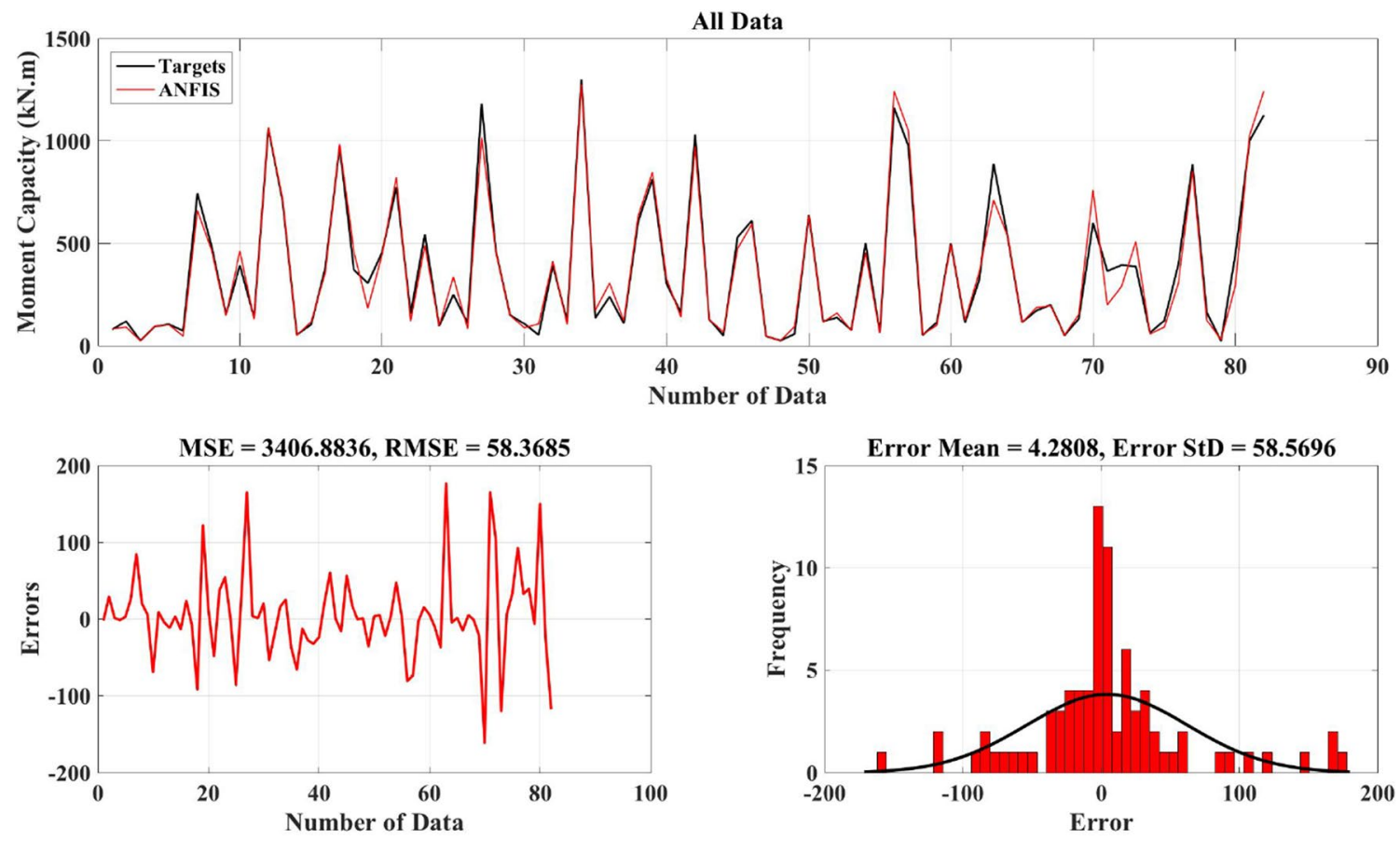

Fig. 7 Results for all data

prediction. Figure 7 illustrated the results of ANFIS for all of 82 datasets.

Figure 8 shows the effect of changes in input variables $(X 1, \ldots, X 5)$ on the output parameter $(Y)$. In drawing each of these graphs, the values of the three variables from the five input variables are considered constant, which is equal to its corresponding median value (see Table 2), and the values of the other two variables have been varied between -1 and 1. Then, the output value for this database is calculated and plotted.

\section{Conclusion}

This paper presents a neuro-fuzzy inference system namely ANFIS to predict the moment capacity of spiralreinforced concrete columns which are failed in flexure. For this purpose, a collection of 82 datasets were used to train and test the model. The system created based on five input parameters including longitudinal reinforcement, transverse reinforcement index, axial force, diameter to length ratio and also a shear force to calculate the target (moment capacity). The proposed ANFIS used Fuzzy $\mathrm{C}$-means approach to determine its unknown coefficients. Also, four clusters and Gaussian membership functions are applied to creating the neuro-fuzzy model. The results of the paper in both training and testing phases indicated that this type of soft computing methods with high accuracy could be considered for predicting the moment capacity of the considered RC columns. The model presented in this article has many applications in the design of concrete structures. Also, due to the proposed neuro-fuzzy model in a mathematical framework, it is an efficient and feasible model. Therefore, it is easy for engineers to understand the equations of this paper and to use them for their purposes. In the future works, other soft computing methods can be used to estimate the moment capacity of the RC columns. 

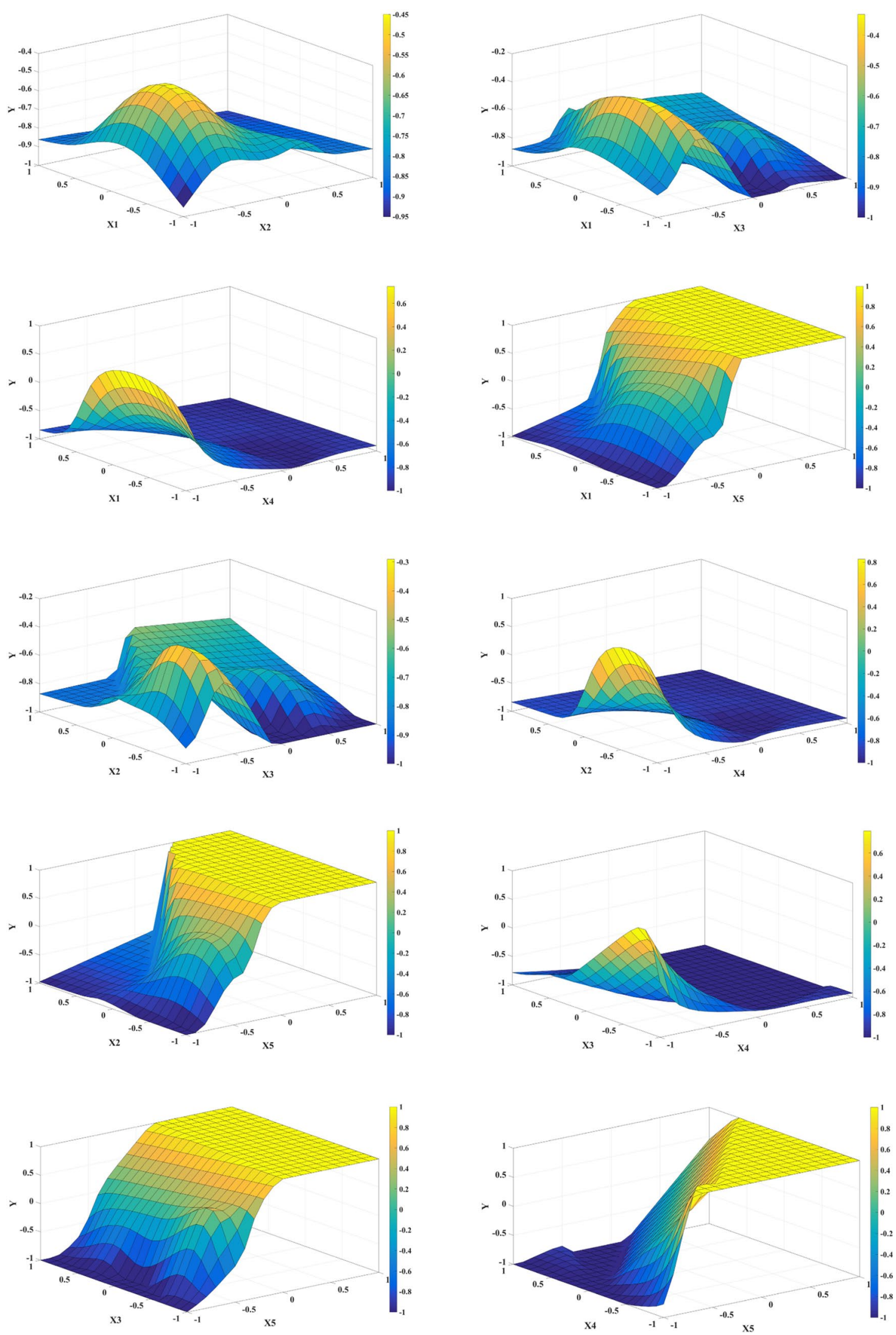

Fig. 8 The effect of input changes on the considered output 
Open Access This article is distributed under the terms of the Creative Commons Attribution 4.0 International License (http://creativeco mmons.org/licenses/by/4.0/), which permits unrestricted use, distribution, and reproduction in any medium, provided you give appropriate credit to the original author(s) and the source, provide a link to the Creative Commons license, and indicate if changes were made.

\section{Appendix}

\begin{tabular}{|c|c|c|c|c|c|c|}
\hline $\begin{array}{l}\text { Data ID in PEER } \\
\text { report [48] }\end{array}$ & $X 1$ & $X 2$ & $X 3$ & $X 4$ & $X 5$ & $Y$ \\
\hline 1 & 29.3232 & 4.1349 & 380 & 0.1818 & 180 & 527 \\
\hline 2 & 27.8250 & 3.9448 & 380 & 0.2857 & 334 & 600 \\
\hline 3 & 28.8027 & 4.4521 & 380 & 0.1538 & 142 & 485 \\
\hline 4 & 19.5963 & 12.2535 & 26.4 & 0.1832 & 133 & 365 \\
\hline 5 & 22.3319 & 14.0117 & 16.9 & 0.1866 & 36 & 49 \\
\hline 6 & 20.1345 & 15.5564 & 550 & 0.2688 & 61 & 72 \\
\hline 7 & 28.7862 & 9.0031 & 680 & 0.2500 & 139 & 250 \\
\hline 8 & 26.2611 & 15.0316 & 2111 & 0.2500 & 163 & 303 \\
\hline 9 & 25.9257 & 7.9225 & 1920 & 0.5000 & 687 & 887 \\
\hline 11 & 22.3796 & 10.2857 & 3785 & 0.5000 & 781 & 1000 \\
\hline 12 & 22.9542 & 22.4862 & 3385 & 0.5000 & 812 & 1060 \\
\hline 13 & 22.9542 & 22.4862 & 6770 & 0.5000 & 937 & 1124 \\
\hline 22 & 47.9465 & 12.6903 & 751 & 0.4000 & 364 & 401 \\
\hline 39 & 25.3533 & 8.9449 & 555 & 0.2500 & 142 & 240 \\
\hline 40 & 30.3300 & 19.3304 & 2080 & 0.2500 & 175 & 324 \\
\hline 41 & 21.5670 & 5.9520 & 2652 & 0.2500 & 212 & 393 \\
\hline 42 & 22.1200 & 12.7400 & 3620 & 0.2500 & 207 & 394 \\
\hline 43 & 35.6211 & 11.2105 & 907 & 0.5000 & 461 & 394 \\
\hline 45 & 41.0811 & 11.5135 & 1813 & 0.5000 & 579 & 499 \\
\hline 50 & 72.3293 & 26.0580 & 151 & 0.1333 & 14 & 22 \\
\hline 51 & 72.3293 & 26.0580 & 151 & 0.2667 & 37 & 24 \\
\hline 52 & 72.3293 & 26.0580 & 220 & 0.2667 & 36 & 24 \\
\hline 55 & 36.6423 & 25.8012 & 120 & 0.3333 & 59 & 50 \\
\hline 56 & 38.2286 & 26.9182 & 239 & 0.3333 & 73 & 63 \\
\hline 57 & 34.7669 & 12.7433 & 120 & 0.1667 & 32 & 57 \\
\hline 58 & 36.1918 & 25.4840 & 120 & 0.3333 & 63 & 51 \\
\hline 59 & 36.3407 & 25.5889 & 239 & 0.3333 & 77 & 64 \\
\hline 60 & 37.9004 & 13.8918 & 120 & 0.1667 & 30 & 52 \\
\hline 61 & 6.7755 & 38.0453 & 184 & 0.6667 & 117 & 46 \\
\hline 63 & 11.9858 & 11.6981 & 322 & 0.5000 & 102 & 53 \\
\hline 66 & 28.0585 & 36.0964 & 322 & 0.5000 & 146 & 76 \\
\hline 80 & 44.6502 & 16.3112 & 0 & 0.6111 & 176 & 79 \\
\hline 84 & 47.6980 & 17.4246 & 215 & 0.6111 & 209 & 96 \\
\hline 85 & 45.8213 & 7.8698 & 215 & 0.4583 & 151 & 93 \\
\hline 90 & 45.2282 & 7.7680 & 430 & 0.4583 & 167 & 104 \\
\hline 93 & 31.5145 & 14.0676 & 200 & 0.2223 & 74 & 115 \\
\hline
\end{tabular}

\begin{tabular}{|c|c|c|c|c|c|c|}
\hline $\begin{array}{l}\text { Data ID in PEER } \\
\text { report [48] }\end{array}$ & $X 1$ & $X 2$ & $X 3$ & $X 4$ & $X 5$ & $Y$ \\
\hline 94 & 31.5145 & 14.0676 & 200 & 0.2223 & 75 & 120 \\
\hline 95 & 25.7442 & 11.4918 & 222 & 0.2223 & 72 & 111 \\
\hline 96 & 25.7442 & 11.4918 & 222 & 0.2223 & 77 & 123 \\
\hline 97 & 25.7442 & 11.4918 & 222 & 0.2223 & 77 & 119 \\
\hline 98 & 27.8634 & 12.4378 & 222 & 0.2223 & 79 & 120 \\
\hline 99 & 27.8634 & 12.4378 & 222 & 0.2223 & 68 & 107 \\
\hline 100 & 28.1206 & 12.5526 & 222 & 0.2223 & 75 & 114 \\
\hline 101 & 33.8489 & 15.1096 & 200 & 0.2223 & 74 & 113 \\
\hline 102 & 33.8489 & 15.1096 & 200 & 0.2223 & 68 & 103 \\
\hline 103 & 33.8489 & 15.1096 & 200 & 0.2223 & 72 & 109 \\
\hline 106 & 29.4477 & 8.9650 & 1780 & 0.1667 & 285 & 1300 \\
\hline 107 & 26.9001 & 12.8049 & 1928 & 0.5022 & 535 & 530 \\
\hline 109 & 26.1491 & 12.4474 & 970 & 0.5022 & 510 & 501 \\
\hline 112 & 72.3743 & 37.7307 & 1914 & 0.5022 & 957 & 975 \\
\hline 113 & 47.1787 & 11.1858 & 1780 & 0.1250 & 101 & 544 \\
\hline 114 & 43.1685 & 6.5550 & 1780 & 0.1250 & 124 & 639 \\
\hline 115 & 44.7342 & 10.6062 & 1780 & 0.1250 & 117 & 611 \\
\hline 116 & 22.2041 & 13.7010 & 653.856 & 0.2500 & 269 & 708 \\
\hline 117 & 22.2041 & 13.7010 & 653.856 & 0.1250 & 130 & 745 \\
\hline 118 & 22.2041 & 13.7010 & 653.856 & 0.0670 & 80 & 604 \\
\hline 119 & 11.1766 & 13.7010 & 653.856 & 0.2500 & 172 & 443 \\
\hline 120 & 44.4082 & 13.7010 & 653.856 & 0.2500 & 448 & 1180 \\
\hline 121 & 34.9187 & 15.6526 & 911.84 & 0.3333 & 525 & 1030 \\
\hline 122 & 34.9187 & 15.6526 & 911.84 & 0.1250 & 172 & 975 \\
\hline 123 & 34.9187 & 15.6526 & 911.84 & 0.0670 & 157 & 1160 \\
\hline 125 & 24.8601 & 6.7266 & 400 & 0.3333 & 411 & 775 \\
\hline 126 & 26.8218 & 10.6527 & 400 & 0.3333 & 433 & 815 \\
\hline 127 & 21.1434 & 23.6923 & 1000 & 0.1520 & 55 & 138 \\
\hline 128 & 21.1434 & 22.5508 & 1000 & 0.1520 & 53 & 132 \\
\hline 129 & 15.2702 & 17.1111 & 1850 & 0.1520 & 56 & 163 \\
\hline 130 & 15.2702 & 11.2778 & 1850 & 0.1520 & 55 & 162 \\
\hline 131 & 15.2702 & 8.1200 & 1850 & 0.1520 & 57 & 154 \\
\hline 132 & 15.2702 & 17.1111 & 925 & 0.1520 & 59 & 139 \\
\hline 133 & 15.2702 & 17.1111 & 1850 & 0.1520 & 55 & 158 \\
\hline 134 & 15.2702 & 16.0067 & 1850 & 0.1520 & 71 & 200 \\
\hline 136 & 8.2647 & 1.0506 & 1139 & 0.3333 & 279 & 456 \\
\hline 141 & 18.5048 & 11.4175 & 1308 & 0.2500 & 207 & 889 \\
\hline 150 & 15.4853 & 11.4719 & 987.5 & 0.2129 & 144 & 372 \\
\hline 151 & 15.0447 & 11.4719 & 987.5 & 0.2129 & 152 & 388 \\
\hline 152 & 35.9624 & 12.2208 & 231.3 & 0.1875 & 180 & 462 \\
\hline 153 & 34.3851 & 11.6848 & 231.3 & 0.1875 & 150 & 382 \\
\hline 154 & 37.0969 & 12.6063 & 231.3 & 0.1875 & 94 & 306 \\
\hline 155 & 34.6894 & 11.7882 & 231.3 & 0.1875 & 70 & 130 \\
\hline 156 & 26.8745 & 4.1345 & 700 & 0.1596 & 74 & 136 \\
\hline 157 & 14.6971 & 10.0410 & 0 & 0.2192 & 143 & 150 \\
\hline 158 & 14.6971 & 10.0410 & 0 & 0.2192 & 164 & 172 \\
\hline
\end{tabular}




\section{References}

1. Panagiotakos T, Fardis M (1998) Effect of column capacity design on earthquake response of reinforced concrete buildings. J Earthq Eng 2:113-145

2. Hernández-Montes E, Aschheim M, Gil-Martin L (2004) Impact of optimal longitudinal reinforcement on the curvature ductility capacity of reinforced concrete column sections. Mag Concrete Res 56:499-512

3. Chen Z-H, Li Z-Y, Rong B, Liu X-L (2006) Experiment of axial compression bearing capacity for crisscross section special shaped column composed of concrete filled square steel tubes. J Tianjin Univ 11:1275-1282

4. Chen Z, Liu F, Zheng H, Xue J (2010) Research on the bearing capacity of recycled aggregate concrete-filled circle steel tube column under axial compression loading. In: International conference on mechanic automation and control engineering (MACE), pp $1198-1201$

5. Li Y (2017) Nonlinear finite element bearing capacity and seismic analysis of steel tubular recycled concrete column. Boletín Técnico, vol 55, ISSN: 0376-723X

6. Shi X (2017) 67. An optimization method for calculating bearing capacity of steel pipe recycled concrete column based wavelet analysis. Boletín Técnico, vol 55, ISSN: 0376-723X

7. Naderpour H, Mirrashid M (2019) Shear failure capacity prediction of concrete beam-column joints in terms of anfis and gmdh. Pract Period Struct Des Constr 24:04019006. https://doi. org/10.1061/(asce)sc.1943-5576.0000417

8. Naderpour H, Mirrashid M, Nagai K (2019) An innovative approach for bond strength modeling in FRP strip-to-concrete joints using adaptive neuro-fuzzy inference system. Eng Comput. https://doi.org/10.1007/s00366-019-00751-y

9. Naderpour H, Mirrashid M (2019) Classification of failure modes in ductile and non-ductile concrete joints. Eng Fail Anal 103:361375. https://doi.org/10.1016/j.engfailanal.2019.04.047

10. Naderpour H, Nagai K, Haji M, Mirrashid M (2019) Adaptive neuro-fuzzy inference modelling and sensitivity analysis for capacity estimation of fiber reinforced polymer-strengthened circular reinforced concrete columns. Expert Syst 36(4):e12410. https://doi.org/10.1111/exsy.12410

11. Mirrashid M, Givehchi M, Miri M, Madandoust R (2016) Performance investigation of neuro-fuzzy system for earthquake prediction. Asian J Civ Eng 17:213-223

12. Mirrashid M (2014) Earthquake magnitude prediction by adaptive neuro-fuzzy inference system (ANFIS) based on fuzzy C-means algorithm. Nat Hazards 74:1577-1593. https://doi.org/10.1007/ s11069-014-1264-7

13. Bui K-TT, Bui DT, Zou J, Van Doan C, Revhaug I (2018) A novel hybrid artificial intelligent approach based on neural fuzzy inference model and particle swarm optimization for horizontal displacement modeling of hydropower dam. Neural Comput Appl 29:1495-1506. https://doi.org/10.1007/s00521-016-2666-0

14. Mansouri I, Gholampour A, Kisi O, Ozbakkaloglu T (2018) Evaluation of peak and residual conditions of actively confined concrete using neuro-fuzzy and neural computing techniques. Neural Comput Appl 29:873-888. https://doi.org/10.1007/s0052 1-016-2492-4

15. Naderpour H, Vahdani R, Mirrashid M (2018) Soft computing research in structural control by mass damper (a review paper). In: Presented at the 4th international conference on structural engineering, Tehran

16. Naderpour H, Mirrashid M (2018) An innovative approach for compressive strength estimation of mortars having calcium inosilicate minerals. J Build Eng 19:205-215. https://doi.org/10.1016/j. jobe.2018.05.012
17. Naderpour H, Mirrashid M (2017) Compressive strength of mortars admixed with wollastonite and microsilica. Mater Sci Forum 890:415-418. https://doi.org/10.4028/http://www.scientific.net/ MSF.890.415

18. Naderpour H, Mirrashid M (2019) Evaluation and verification of finite element analytical models in reinforced concrete members. Iran J Sci Technol Trans Civ Eng. https://doi.org/10.1007/s4099 6-019-00240-8

19. Kheyroddin A, Mirrashid M, Arshadi H (2017) An investigation on the behavior of concrete cores in suspended tall buildings. Iran J Sci Technol Trans Civ Eng 41:383-388. https://doi.org/10.1007/ s40996-017-0075-y

20. Liu X, Wei H, Wu T, Liu BQ, Zhang Y (2015) Shear strength of reinforced concrete frame column by neural network model. In: Advanced materials research, pp 1234-1239

21. Jakubek M (2017) Fuzzy weight neural network in the analysis of concrete specimens and R/C column buckling tests. Comput Assist Methods Eng Sci 18:243-254

22. Xu Y, Wei S, Bao Y, Li H (2019) Automatic seismic damage identification of reinforced concrete columns from images by a region-based deep convolutional neural network. Struct Control Health Monit. https://doi.org/10.1002/stc.2313

23. Jang J-S (1993) ANFIS: adaptive-network-based fuzzy inference system. IEEE Trans Syst Man Cybern 23:665-685. https://doi. org/10.1109/21.256541

24. Aguilar L, Melin P, Castillo O (2003) Intelligent control of a stepping motor drive using a hybrid neuro-fuzzy ANFIS approach. Appl Soft Comput 3:209-219. https://doi.org/10.1016/S1568 -4946(03)00035-8

25. Castillo O, Melin P (2003) Intelligent adaptive model-based control of robotic dynamic systems with a hybrid fuzzy-neural approach. Appl Soft Comput 3:363-378. https://doi.org/10.1016/j. asoc.2003.05.007

26. Melin P, Castillo O (2004) Intelligent control of a stepping motor drive using a hybrid neuro-fuzzy approach. Soft Comput 8:546555. https://doi.org/10.1007/s00500-003-0313-z

27. Melin P, Soto J, Castillo O, Soria J (2012) A new approach for time series prediction using ensembles of ANFIS models. Expert Syst Appl 39:3494-3506. https://doi.org/10.1016/j. eswa.2011.09.040

28. Soto J, Melin P, Castillo O (2014) Time series prediction using ensembles of ANFIS models with genetic optimization of interval type-2 and type-1 fuzzy integrators. Int J Hybrid Intell Syst 11:211-226. https://doi.org/10.3233/HIS-140196

29. Naderpour H, Mirrashid M (2015) Application of soft computing to reinforced concrete beams strengthened with fibre reinforced polymers: a state-of-the-art review. In: Computational techniques for civil and structural engineering, vol 38. Saxe-Coburg Publications, Stirlingshire, pp 305-323

30. Mirrashid M (2017) Comparison study of soft computing approaches for estimation of the non-ductile $\mathrm{RC}$ joint shear strength. Soft Comput Civ Eng 1:12-28. https://doi.org/10.22115 /scce.2017.46318

31. Naderpour H, Mirrashid M (2019) Shear strength prediction of $\mathrm{RC}$ beams using adaptive neuro-fuzzy inference system. Sci Iran. https://doi.org/10.24200/sci.2018.50308.1624

32. Davey B (1975) Reinforced concrete bridge piers under seismic loading, master of engineering report. Civil Engineering Department, University of Canterbury, Christchurch

33. Munro I, Park R, Priestley M (1976) Seismic behaviour of reinforced concrete bridge piers. Department of Civil Engineering, University of Canterbury, Christchurch, pp 76-79

34. Ng Kit H, Priestley MJN, Park R (1978) Seismic behaviour of circular reinforced concrete bridge piers: a report submitted in partial fulfilment of the requirements for the Degree of Master of Engineering at the University of Canterbury, Christchurch, 
New Zealand. Department of Civil Engineering, University of Canterbury

35. Kenchiku K (1978) Aseismic analysis of building structural members: a list of experimental results on deformation ability of reinforced concrete columns under large deflection (No. 3). Building Research Institute, Ministry of Construction, Japan

36. Ng Kit H, Priestley MJN, Park R (1978) Seismic behaviour of circular reinforced concrete bridge piers. Department of Civil Engineering, University of Canterbury, Christchurch, p 78-14

37. Potangaroa RT, Priestley M, Park R (1979) Ductility of spirally reinforced concrete columns under seismic loading: a report submitted in partial fulfilment of the requirements for the Degree of Master of Engineering at the University of Canterbury: Department of Civil Engineering, University of Canterbury

38. Ang BG, Priestley MJN, Park R (1981) Ductility of reinforced concrete bridge piers under seismic loading. Department of Civil Engineering, University of Canterbury, Christchurch, pp 81-83

39. Arakawa T, Arai Y, Egashira K, Fujita Y (1982) Effects of the rate of cyclic loading on the load-carrying capacity and inelastic behavior of reinforced concrete columns. Trans Japan Concrete Inst 4:485-492

40. Petrovski J, Ristic D (1984) Reversed cyclic loading test of bridge column models. Report IZIIZ, pp 84-164

41. Ang BG, Priestley MJN, Park R (1985) Seismic shear strength of circular bridge piers. Department of Civil Engineering, University of Canterbury, Christchurch, p 85-5

42. Zahn FA (1985) Design of reinforced concrete bridge columns for strength and ductility. Department of Civil Engineering, University of Canterbury, Christchurch, pp 86-87

43. Cheok G, Stone WC (1986) Behavior of 1/6-scale model bridge columns subjected to cycle inelastic loading, NBSIR 86-3494. Center for Building Technology, National Engineering Laboratory, National Institute of Standards and Technology, 1986

44. Arakawa T, He M-X, Arai Y, Mizoguchi M (1988) Shear resisting behavior of reinforced concrete columns with spiral hoops. Trans Japan Concrete Inst 10:155-162

45. Arakawa T, Arai Y, Mizoguchi M, Yoshida M (1989) Shear resisting behavior of short reinforced concrete columns under biaxial bending-shear. Trans Japan Concrete Inst 11:317-324

46. Stone WC, Cheok GS (1989) Inelastic behavior of full-scale bridge columns subjected to cyclic loading, NIST BSS 166. Building Science Series, Center for Building Technology, National Engineering Laboratory, National Institute of Standards and Technology

47. Watson S, Park R (1989) Design of reinforced concrete frames of limited ductility. Department of Civil Engineering, University of Canterbury, Christchurch, p 89-4

48. McLean DI, Lim K-Y (1990) Moment-reducing hinge details for the bases of bridge columns. Final report, Research project GC 8287, Task 5, Plastic hinge details. Washington State Department of Transportation, Planning, Research and Public Transportation Division

49. Wong YL (1990) Squat circular bridge piers under multi-directional seismic attack: a thesis submitted in partial fulfilment of the requirements for the Degree of Doctor of Philosophy in Civil Engineering at the University of Canterbury, University of Canterbury

50. Chail YH, Priestley MN, Seible F (1991) Seismic retrofit of circular bridge columns for enhanced flexural performance. Struct J 88:572-584
51. Coffman HL, Marsh ML, Brown CB (1993) Seismic durability of retrofitted reinforced-concrete columns. J Struct Eng 119:1643-1661. https://doi.org/10.1061/ (ASCE)0733-9445(1993)119:5(1643)

52. Priestley MN, Benzoni G (1996) Seismic performance of circular columns with low longitudinal reinforcement ratios. Struct J 93:474-485

53. Sritharan S, Priestley MN, Seible F (1996) Seismic response of column/cap beam tee connections with cap beam prestressing. University of California, San Diego, ssrp-96/09

54. Hose YD, Seible F, Priestley MJN (1997) Strategic relocation of plastic hinges in bridge columns. University of California, San Diego, Structural Systems Research Project, 97/05

55. Kunnath SK, El-Bahy A, Taylor A, Stone W (1997) Cumulative seismic damage of reinforced concrete bridge piers. National Center for Earthquake Engineering Research Technical Report NCEER-97-0006

56. McDaniel CC (1997) Scale effects on the shear strength of circular reinforced concrete columns. University of California, San Diego

57. Henry L, Mahin S (1999) Study of buckling of longitudinal bars in reinforced concrete bridge columns. Report to the California Department of Transportation

58. Kowalsky MJ, Priestly MN, Seible F (1999) Shear and flexural behavior of lightweight concrete bridge columns in seismic regions. ACI Struct J 96:136-148

59. Saatcioglu M, Baingo D (1999) Circular high-strength concrete columns under simulated seismic loading. J Struct Eng 125:272280. https://doi.org/10.1061/(ASCE)0733-9445(1999)125:3(272)

60. Vu NHD, Priestly MJ, Seible F, Benzoni G (1999) The seismic response of well-confined circular reinforced concrete columns with low aspect ratios (No. SSRP-97/15)

61. Lehman DE (2000) Seismic performance of well-confined concrete bridge columns. Pacific Earthquake Engineering Research Center PEER 1998/01

62. Nelson JM (2000) Damage model calibration for reinforced concrete bridge columns. University of Washington

63. Calderone A, Lehman DE, Moehle JP (2001) Behavior of reinforced concrete bridge columns having varying aspect ratios and varying lengths of confinement: Pacific Earthquake Engineering Research Center

64. Roeder C, Graff R, Soderstrom J, Yoo J (2001) Seismic performance of pile-wharf connections. Peer report 2002/07. Pacific Earthquake Engineering Research Center, University of California, Berkeley

65. Hamilton C, Pardoen G, Kazanjy R (2002) Experimental testing of bridge columns subjected to reversed-cyclic and pulse-type loading histories. Report 2001-03. Civil Engineering Technical Report Series, University of California, Irvine

66. Berry M, Parrish M, Eberhard M (2004) PEER structural performance database user's manual (version 1.0). University of California, Berkeley

Publisher's Note Springer Nature remains neutral with regard to jurisdictional claims in published maps and institutional affiliations. 